\title{
Librarians and the War
}

\section{President Brown's opening remarks at the meeting of the A.L.A. Council, December 29, I94I.}

$\mathrm{F}_{\mathrm{s}}^{\text {or }}$ R All Americans, but for librarians particularly, the events of the last few weeks as well as the history of the past twenty years have special significance. We librarians, together with other groups of educators, have a vital interest in the outcome of this war. A victory for the aggressors would mean the end of the American public library as we know it. In the British Empire and in the United States the public library has developed as a result of basic principles of freedom of speech and respect for individual rights. The triumph of the Nazi doctrine would destroy our freedom of thought, our right to study both sides of the question, and our privilege to read and think for ourselves. These are the fundamental principles to which we librarians have dedicated our lives. They are fundamental to librarianship.

These principles date back to the American Bill of Rights, adopted I 50 years ago, and in part admirably summarized seventy-five years ago. The words of Abraham Lincoln apply far more strongly today than they did in 1865 , if by civil war we understand a war for civilization. "Now we are engaged in a great civil war, testing whether that nation, or any nation so conceived and so dedicated, can long endure. ..."

\section{Failure of Librarians}

A consideration of past mistakes is valuable as a means of avoidance of mistakes in the future. Although the fundamental principles of American librarianship have been seriously threatened by the ideologies which developed during the last ten years, we librarians have failed to understand, and to aid our communities to understand, the significance of nationalistic movements. Since we ourselves have not understood, we could not lead others. Mr. MacLeish warned us eighteen months ago at Cincinnati and urged us to exert leadership in our communities. ${ }^{1}$ We could not, even as late as I940, unitedly listen to his appeal. At the same meeting one group of librarians, fortunately a small one, issued a request to the President that no military aid be sent to Great Britain. If it had not been for the courage of the British, if it had not been that the people of the United States in general favored a policy of assistance, then the future of this country and of our democracy would be dark indeed.

The indifference and lack of understanding by our own people are partly responsible for the tragedy at Pearl Harbor. The material for the bombs which killed our soldiers and sailors at Pearl Harbor and the gasoline which brought the bombers there, may well have come from the United States. We sold the

\footnotetext{
1 MacLeish, Archibald. "The Librarian and the Democratic Process." A.L.A. Bulletin 34:385-88, 42I-22, June 1940; also 34:4I9, June 1940.
} 
Japanese material to use for killing our people. Even while we were criticizing the policy of the British appeasers, the futility of our own policy of appeasement was not understood by the American people.

Pearl Harbor clearly indicates that the Atlantic and Pacific oceans are no protection. Pearl Harbor is farther from Japan than Boston from the European continent. If the recent disaster has shown the American people the dangers of isolationism, then the sacrifice at Pearl Harbor may not have been in vain.

The officers, boards, and committees of the American Library Association are counting on your undivided loyalty. We have taken the liberty of pledging the support of every member of the A.L.A. in the United States to the government for whatever aid we can give in the prosecution of this war. There is much we can accomplish if we work together wholeheartedly and harmoniously to win the war, leaving less pressing tasks for the postwar period.

\section{Librarians Can Aid}

What can the sixteen thousand members of the American Library Association do to assist in bringing about victory? We certainly cannot continue all our customary professional routines. Much of the work we usually do will have to be abandoned for the duration, to be replaced by education for victory and for a world order which will make future wars impossible.

According to a recent estimate, in 1918 five men were required to manufacture war materials to every soldier in the service. Now the proportion is eighteen to one. We must help in making these war workers efficient. If books are needed in defense areas, if research publications are needed by government technicians or in research departments of manufacturing firms, they must be supplied even if the purchase of fiction and recreational reading is curtailed. No reader must leave a public library without the specific material he needs if he is concerned in any way, directly or indirectly, with war activities. No research department must do without material that can be found anywhere in the United States.

There is an even more important field for librarians-the promotion of civilian morale. Our people must understand the significance of events, the dangers from inflation, the necessity that we support the program of the Treasury in advertising defense bonds, that we cooperate in the understanding and administration of priorities, that we pay careful attention to the maintenance of the health of our citizens. Our libraries must be actual centers of information.

\section{Broad Field}

Civilian morale is one division of a broad field. We librarians must take an active part in the educational work of our communities. We must stimulate thought on international problems. We must encourage study and forum discussions in order that all the American people may understand the danger of isolationism and the need for international cooperation and understanding. If a world order is to be built which will prevent future wars, then it must be done by voters who understand. Furthermore, our people must realize that future world peace cannot be assured by hatred, by enmity, by ignoring the cultures and accomplishments even of our enemies. We librarians can assist in this war by (Continued on page II6) 
they choose to teach with library materials rather than student-bought textbooks will progress be made in teaching with books. Moreover, only insofar as they use the collections for research and public service can those collections become useful in the solution of baffling educational, social, economic, and political problems.

In conclusion, may I personally and on behalf of the board of library trustees and the staff of the Joint University $\mathrm{Li}$ braries express our deep appreciation to those who have helped with their moral and financial support to make the Joint University Library a reality. You have enabled us to take the first important step to provide an adequate library and with your further assistance and encouragement we hope we may take the other essential steps.

\section{Librarians and the War}

(Continued from page Ioo)

enabling the decisions of the American people to be based on the intellect rather than on the emotions. We don't want to repeat the mistakes of the last world war and the peace which followed it.

Let us then as a united group devote our attention for the duration to the education and enlightenment of the American people, first for victory and then for world-wide understanding with no thought of destruction or revenge.

Let us all work for victory and perma-

\section{Libraries and the Long Haul}

\section{(Continued from page IOI)}

edge is not to flicker and burn $\operatorname{dim}$ for decades, institutions of higher learning and their libraries must be prepared to carry on activities of basic research by continuing to an appropriate degree their normal functions.

Problems of both kinds must be met by libraries under conditions of peculiar diffculty. Library personnel is diminishing by induction into the armed services, by attraction to defense work, and through the current reduction and future extinction of N.Y.A. and W.P.A., and, more seriously, by the lowering of income. The avail-

nent security for all nations. This is something more than a fight for you first, or me first, or America first. It must be for the well-being of all peoples of the world. This is indeed the basic doctrine of democracy and of the Christian religion as opposed to the philosophy that one nation or one race must dominate. In the world of tomorrow no nation can secure the well-being of its own people without regard for the needs of other peoples.

ability of essential library supplies is becoming increasingly less. Humble examples are the increasing costs and ultimate shortage of catalog card stock and shortages in the essential materials for binding. Important publications for research published in foreign countries are generally unavailable in this country for many reasons. Only by hard work and ingenuity can we meet the current and pressing demands and at the same time keep our houses in order for the future. It will be a long haul but we are going to make it! 